\title{
Assessment of the Potential of Groundwater Supplementation by Estimating the Stabilization Value of Tank Irrigation Systems in Tamil Nadu, India
}

\author{
A. Nanthakumaran ${ }^{*}$ and K. Palanisami ${ }^{1}$ \\ Department of Biological Science \\ Faculty of Applied Sciences, Vavuniya Campus \\ Sri Lanka
}

\begin{abstract}
Irrigation tanks are one of the oldest and most important common property water resources in the resource poor regions especially in South India and Sri Lanka. Tank irrigation accounts for more than 30\% of total irrigated area in South Indian states. In Tamil Nadu alone there are 39200 tanks of varying sizes and types. Variation in rainfall quantity (total amount) and quality (intensity) significantly affects tank water supplies. This resulted in declining performance of the tanks. The objective of this study was to calculate the stabilization value of groundwater in the tank irrigation systems. Cross sectional data in the year 2006/2007 on water storage in randomly selected twelve tanks in these two districts, of which ten tanks in Sivagangai district and two tanks in Madurai district of Tamil Nadu were taken for this study. These two districts were selected as they are identical in using tank water supply with ground water. Keeping the importance of groundwater in the tank system, the stabilization value was worked out using the stabilization value model, which was found to be Rs. 291,123. The results confirm that the positive and higher value of groundwater in the tank system justify the need for investment in wells in the tank command area. Thus, keeping the balance of tank water and groundwater, the performance of the tanks could be stabilized.
\end{abstract}

Key words: Groundwater, Stabilization value, Tank performance, Tank water.

\section{INTRODUCTION}

Tank irrigation contributes significantly to agricultural production in South and Southeast Asia. Irrigation tanks are one of the oldest and most important common property water resources in the resource poor regions especially in South India and Sri Lanka. Tank irrigation accounts for more than 30\% of total irrigated area in Andra Pradesh, Karnataka and Tamil Nadu states in India. In Tamil Nadu alone there are 39200 tanks of varying sizes and types. Of these tanks, 22\% are under public works department (PWD) (which have a command area of more than 40 ha and are maintained by the irrigation department) while the others are under Panchayat union (PU) (which have a command area of less than 40 ha and are managed by local villages). The small tanks are also grouped under this category. Generally, rice is grown from September to January where the average rainfall during this period varies from 300 to $450 \mathrm{~mm}$. Tanks are not only useful in irrigation, but also important

To whom correspondence should be addressed to: ananthi@hotmail.com

IWMI-TATA Policy Research Program, International Water Management Institute, South Asia Regional

Office, Hyderabad, India 
in enriching enriches the water table through percolation. The latter is extremely useful in ensuring sustained agriculture in the tank region.

Variation in rainfall quantity (total amount) and quality (intensity) significantly affects tank water supplies. Rainfall variation during a season can seriously affect tank storage. Tank encroachment, siltation, and disrepair of sluice and lack of maintenance activities in the tanks also affect tank storage. This resulted in declining performance of the tanks. At present one of the important components in tank irrigation is wells in the tank command.

Water supply fluctuates from one tank to another within a year and over the years. Even though the tanks are in a homogenous region and inter tank differences in terms of rainfall, storage pattern, filling pattern and irrigation pattern are observed to be the same, there is fluctuation in tank water supply in a year. Rainfall variation is responsible for fluctuation in tank water supply over the years. Tank irrigation has undergone a process of rapid decline in the recent past due to its poor performance, which resulted in heavy dependence on ground water supplementation. Ground water stocks, on the other hand, are relatively stable because the wells get the recharge both from tanks and the irrigated rice fields (Palanisami and Easter, 2000). Hence it is important to examine what is the value of the groundwater used in the tank irrigation systems.

Because of inadequate tank supplies, groundwater supplementation is gaining importance. Generally, the number of supplemental tank irrigations required by the farmers could not be met as only about $15 \%$ of the farmers owned wells in the tank command area. Most of the farmers in tank areas are marginal farmers having less than one hectare and it is expensive for them to invest in wells to meet the supplemental water requirements. Investment in community wells by the government or encouragement of farmers to invest on private wells will make all the farmers to share tank and well water. However, this will be possible only when the value attributed to the groundwater supplementation (stabilization value of groundwater) is attractive. Further, such information will also help to examine the options like tank rehabilitation and groundwater use in the tank systems. The concept of 'stabilization value of groundwater was introduced by Tsur (1997). This concept gains importance in tank irrigation systems of Tamil Nadu at the system level, to justify the subsequent investment in new wells by the farmers or the Government agencies. The objective of this study is to calculate the stabilization value of groundwater in the tank irrigation systems in Tamil Nadu to justify the additional wells in the tank irrigation system which is an urgent need to revert the declining performance of the irrigation tanks in Tamil Nadu.

\section{MATERIALS AND METHODS}

\section{Stabilization value of groundwater - theoretical framework}

The basic principles underlying the economics of conjunctive use of surface and groundwater for irrigation are well described by Tsur (1997) and later by Ranganathan and Palanisami (2000). However, a review of some of the important concepts is warranted here for application in the model which follows. Information on as to how the demand for irrigation water was obtained trough reviewed. The demand for surface water and groundwater was determined, and how this in turn can be used to determine the overall value and stabilization value of groundwater was also established. Assume that farmers grow a 
single crop whose water response function is $F(w)$. This function gives the expected yield to each amount of water ' $w$ ' applied for irrigating the crop. Typically $F$ increases initially with increase in $w$, reaches maximum and then decreases i.e. $F(w)$ increases with $w$ at a diminishing rate. If $p_{y}$ denotes the price per unit of yield, then, the revenue generated, denoted by $Y(w)$ is given by $Y(w)=p_{y} F(w)$. If $p_{w}$ stands for the cost per unit of irrigated water, then the profit realized by applying ' $w$ ' amount of water to the crop is $\pi(w)=p_{y} F(w)-p_{w} w$.

For profit maximization, $\frac{d \pi}{d w}=p_{y} \frac{d F}{d w}-p_{w}=0$ or $p_{y} \frac{d F}{d w}=p_{w}$. The term $p_{y} \frac{d F}{d w}$ denotes the marginal productivity of irrigated water. Therefore, So profit will reach a maximum at an amount ' $w$ ' when marginal productivity equals the marginal cost. Profit seeking farmers will demand an additional unit of water as long as the marginal productivity exceeds the revenue this unit generates. Let us denote $p_{y} \frac{d F}{d w}$ by $D(w)$. For a given value of $p_{w}$, the amount of water demanded, $w$ is obtained by solving the equation $D(w)=p_{w}$. As $p_{w}$ varies, $w$ will also vary to satisfy the above equation. The graph of the above equation is called derived demand curve for irrigation water. If the farmers are growing several crops, then, the derived demand curve for irrigation water is obtained by summing the derived demand curves over all crops.

The quantity of surface water, denoted by $S$, available for irrigation fluctuates randomly from year to year depending on rainfall and surface irrigation operations. Hence ' $S$ ' can be assumed to be a random variable. Also groundwater is usually more expensive than surface water as it has to be pumped from the well. When surface water is limited, fully rational farmers would demand groundwater to the extent that the cost of groundwater does not exceed the marginal productivity of irrigation water. Mathematically this concept can be stated as follows.

Let $p_{s}$ and $p_{g}$ be the unit prices of surface and groundwater, respectively, then usually $p_{s}<p_{g}$. If the available surface water ' $S$ ' is limited such that $D(s)>p_{g}$, then groundwater is demanded at amount $g$ such that $D(s+g)=p_{g}$. Given the value of $\mathrm{p}_{\mathrm{g}}$, let $K$ be the amount of irrigation water (Fig. 1) satisfying $D(K)=p_{g}$. That is, $K$ is the total amount of water used for irrigation whose marginal productivity is $p_{g}$. Then $g=K-s>0$ when $D(s)>p_{g}$ and $g=0$ when $D(s)=p_{g}$. 


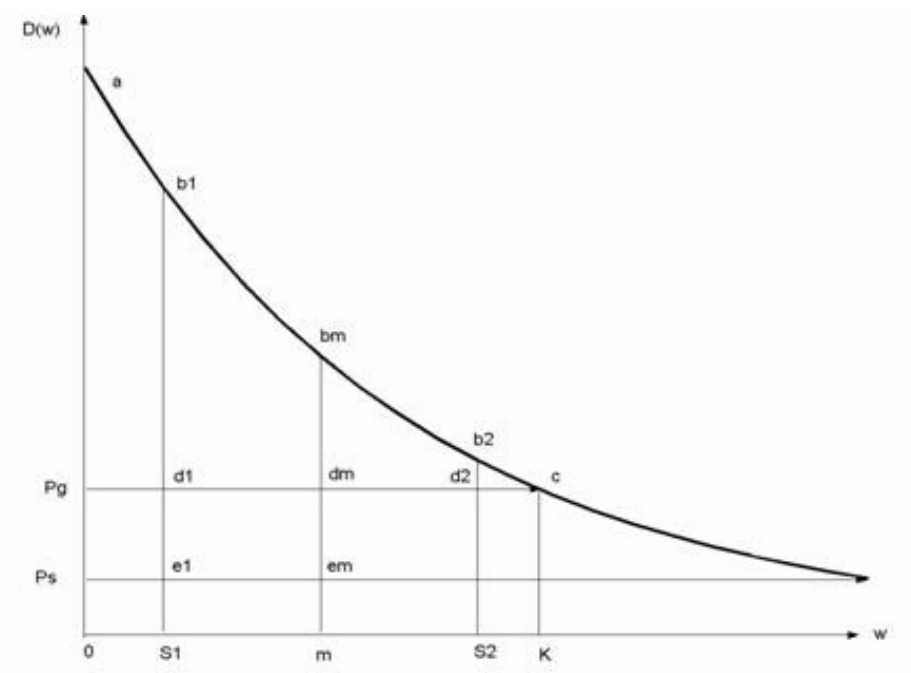

\section{Fig. 1. The Value and stabilization value of groundwater with changes in surface supplies.}

The concepts of value of groundwater and stabilization value of groundwater can be explained by considering a simple case when the surface water $S$ is assumed to fluctuate with values $S=S_{1}$ with a probability of 0.5 and $S=S_{2}$, with probability of 0.5 . When $S=S_{1}$, farmers demand $K-S_{1}$ ha.cm of groundwater which generates an income equal to the area $\left(b_{1} c d_{1}\right)$. Similarly when $S=S_{2}, K-S_{2}$ ha.cm of water will be demanded and the corresponding income will be equal to the area $\left(b_{2} c d_{2}\right)$. The value of groundwater (VG) is defined as the average of the groundwater benefits when $S$ takes the values $S_{1}$ and $S_{2}$. Hence

$$
V G=\frac{1}{2}\left[\operatorname{area}\left(b_{1} c d_{1}\right)+\operatorname{area}\left(b_{2} c d_{2}\right)\right]
$$

Due to the supplementation of irrigation water by groundwater, the total water available for crops is stabilized at level $K$. Thus as indicated by Tsur (1997) groundwater first augments the total water supply for irrigation and then stabilizes the fluctuations in the supply of irrigation water. Therefore, the total value of groundwater is the sum of the above two benefits generated by the groundwater. The benefit generated by the variability reducing function of the groundwater is called as Stabilization Value of Groundwater (SVG).

To explain further this concept, consider a situation that involves two steps. In step 1, available surface water is stabilized at the mean level ' $m$ ' and in the second step irrigation water is augmented by the amount $K-m$ of groundwater. Consider the first step. During wet years, that is during surplus years, $S=S_{2}$. So farmers will store an amount $S_{2}-m$ of surface water. On the other hand during dry years, that is during deficit years (when $S=S_{1}$ ) 
farmers will be withdrawing for irrigation an amount of $m-S_{1}$. The value associated with such water use is the stabilization value of groundwater. With the stable supply of surface water at ' $m$ ', farmers obtain a profit equal to area $\left(a b_{m} e_{m} P_{s}\right)$ each year. With $S=S_{1}$ half of the year and $S=S_{2}$ during the remaining half of the year, farmers earn a profit equal to area $\left(a b_{1} e_{1} P_{s}\right)(1 / 2)+\operatorname{area}\left(a b_{2} e_{2} P_{s}\right)(1 / 2)$ on the average. The difference between the average profit in the above two situations is equal to area $\left(b_{1} b_{m} e_{m} P_{s}\right)(1 / 2)-\operatorname{area}\left(b_{m} b_{2} e_{2} e_{m}\right)(1 / 2)$. Since the derived demand curve for water always slopes downwards, the magnitude of area $\left(b_{1} b_{m} e_{m} P_{s}\right)$ exceeds area $\left(b_{m} b_{2} e_{2} e_{m}\right)$ and hence farmers will prefer the stable situation. The stabilization value of groundwater is therefore equal to

$$
S V G=\operatorname{area}\left(b_{1} b_{m} e_{m} e_{1}\right)\left((0.5)-\operatorname{area}\left(b_{m} b_{2} e_{2} e_{m}\right)(0.5)\right.
$$

This is the maximum amount farmers would be willing to pay to move to a stable supply of surface water. When the surface water is kept at level $m$, irrigation water is supplemented by the groundwater by an amount $K-m$. The value of this component is equal to the area $\left(b_{m} c d_{m}\right)$. So the total value of groundwater is equal to

$$
\begin{aligned}
V G & =S V G+\operatorname{area}\left(b_{m} c d_{m}\right) \\
& =\operatorname{area}\left(b_{1} b_{m} e_{m} e_{1}\right)\left((0.5)-\operatorname{area}\left(b_{m} b_{2} e_{2} e_{m}\right)(0.5)+\operatorname{area}\left(b_{m} c d_{m}\right)\right.
\end{aligned}
$$

\section{Data and method of analysis}

In Sivagangai and Madurai districts of Tamil Nadu state, many tanks use groundwater with tank water supply. Cross sectional data for the year 2007 on water storages in randomly selected twelve tanks out of which ten tanks in Sivagangai district and two tanks in Madurai district of Tamil Nadu were taken for this study. These two districts were selected as they are identical in using tank water supply with ground water.

Regarding the water usage, data relating to various crops in the region, primary and secondary data collected from farm household and from the official records pertaining to 2006-2007 were used. The total quantity of water was calculated by adding the quantity of water from both tank and well irrigations. The average usage of water at experimental and field level situation are more or less the same, as the farmers are using near optimum levels due to water scarcity in the tank. For each crop, various levels of water and corresponding yields were used in the production function analysis. The cost of surface water was calculated based on the prevailing water charges fixed by the Government for different crops in the region. With respect to the cost of groundwater, annualized cost of well was arrived at using $10 \%$ discount rate and 20 years life of the well and using the total hours of pumping, unit cost of groundwater pumped was worked out. Finally, the total water use at the tank level was arrived at summing the water use by different crops by giving due weightage for water losses. Normally, under tank systems, nearly 38\% is lost as seepage and percolation losses from the canal and the fields (Government of Tamil Nadu, 1996). 
A quadratic production function was employed to estimate the crop responses to water for each crop. The quadratic form was used as yield will decline after reaching certain level of water use depicting clearly the diminishing marginal productivity. Earlier studies adopted the quadratic form of production function while analyzing the returns to water input (Palanisami, 2000).

$$
\mathrm{Y}_{\mathrm{i}}=\mathrm{a}+\mathrm{bx}_{\mathrm{i}}-\mathrm{cx}_{\mathrm{i}}^{2}+\mathrm{e}_{\mathrm{i}}
$$

Where, $\mathrm{Y}_{\mathrm{i}}=$ Yield in kg per ha to crop $\mathrm{i}\left(\mathrm{i}=1\right.$ to 5 ), $\mathrm{x}_{\mathrm{i}}=$ Water applied in $\mathrm{cm}$ per ha to crop I and $\mathrm{e}_{\mathrm{i}}=$ error term

Since the main purpose of the model was to capture the influence of water on the crop yield, the model was limited to water only. Using the results of the quadratic production function for various crops, value of marginal products (VMP) was derived for each crop by multiplying the marginal productivity of water by the corresponding output price. The marginal value product and the corresponding water requirements of the different crops were plotted in the histogram. (Fig. 2). the histograms were arranged in the descending order of the marginal value product. Each cell in the histogram corresponds to a particular crop, its height represents the value of marginal productivity of irrigation water and its width gives the total water applied to irrigate the crop (Fig. 2). For developing a smooth curve from the histogram, the following procedure was used. It is assumed an exponential demand function of the form $D(w)=a e^{-k w}$ where $D(w)$ is the VMP of water for a particular crop, ' $w$ ' is the total water used for that crop and $\mathrm{k}$ is the coefficient estimated from the fitted function.

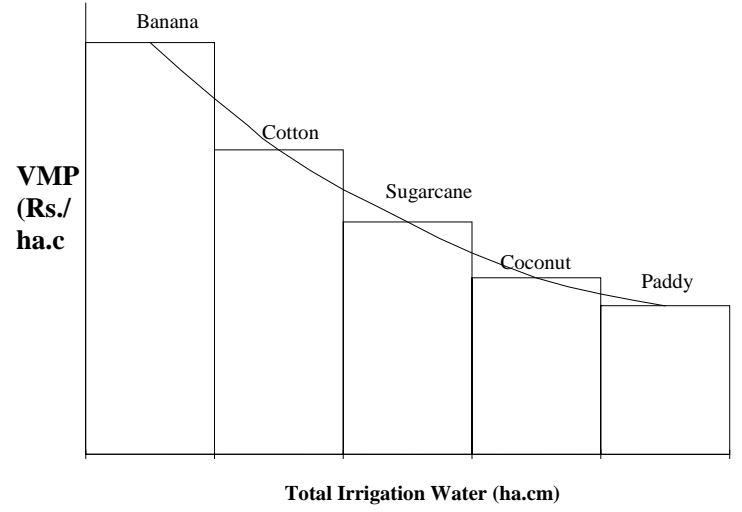

Fig. 2. Value of marginal productivity of water and total water use

The coordinates of the midpoint of each bar in the histogram were calculated and these points were used to estimate the parameters a and $\mathrm{k}$ of the function using standard statistical procedures which includes $\mathrm{T}$ test and regression analysis. Finally, using the resulting demand function, total profit due to irrigation water was calculated by subtracting total cost from the total revenue. The profit with and without groundwater were obtained as follows: 


$$
\begin{aligned}
\pi(s) & =\int_{0}^{s} \mathrm{D}(\mathrm{w}) \mathrm{dw}-\mathrm{p}_{\mathrm{s}} \\
& =\mathrm{a} \int_{0}^{s} \mathrm{e}^{-\mathrm{kw}} \mathrm{dw}-\mathrm{p}_{\mathrm{s}} \mathrm{s} \\
& =(a / k)\left(1-e^{-k s}\right)-\mathrm{p}_{\mathrm{s}} \mathrm{s}
\end{aligned}
$$

Similarly

$$
\pi(s+g)=(a / k)\left(1-e^{-k(s+g)}\right)-\mathrm{p}_{\mathrm{s}} \mathrm{s}-\mathrm{p}_{\mathrm{g} g} \mathrm{\ldots \ldots \ldots \ldots \ldots \ldots \ldots \ldots \ldots \ldots \ldots \ldots \ldots \ldots \ldots \ldots \ldots \ldots \ldots \ldots \ldots \ldots \ldots \ldots \ldots \ldots \ldots \ldots \ldots \ldots \ldots \ldots}
$$

Where,

$\pi=$ Profit in Rs

$\mathrm{s}=$ surface water quantity in ha.cm

$\mathrm{g}=$ ground water quantity in ha.cm

$\mathrm{p}_{\mathrm{s}}=$ price of surface water in Rs/ha.cm

$\mathrm{p}_{\mathrm{g}}=$ price of ground water in Rs/ha.cm

$\mathrm{a}, \mathrm{k}$ are coefficients estimated from the model.

\section{RESULTS AND DISCUSSION}

\section{Supply of surface (tank) and well water}

In the case of these study tanks, the tank supply data in the twelve tanks were estimated using the depth of water at different locations and the water spread area. In the case of groundwater supplies, it was estimated using the details of the wells including water levels in different months, horse power (HP) of the engine and the pumping pattern were worked out and converted into standard units (ha.cm) for comparison purposes. The results were further cross checked by summing up the number of supplemental irrigations given by the farmers

\begin{tabular}{|c|c|c|c|c|}
\hline$\overline{\text { Crop }}$ & Fitted Quadratic function & $\begin{array}{r}\text { MPP } \\
\text { (kg) }\end{array}$ & $\begin{array}{c}P_{y} \\
(\mathrm{Rs} / \mathrm{kg})\end{array}$ & $\begin{array}{l}\text { VMP } \\
\text { (Rs) }\end{array}$ \\
\hline Paddy & $\begin{array}{l}Y_{1}=-2227.58+43.76 X_{1}-.0579 X_{1}^{2} \\
\left(R^{2}=0.73\right)(n=184)\end{array}$ & 35.12 & 7.50 & 263.00 \\
\hline Sugarcane & $\begin{array}{l}Y_{2}=-141312+2092.7 X_{2}-5.86 X_{2}^{2} \\
\left(R^{2}=0.94\right)(n=118)\end{array}$ & 521.00 & 1.00 & 521.00 \\
\hline Coconut & $\begin{array}{l}Y_{3}=-5761.65+133.61 X_{3}-.365 X_{3}^{2} \\
\left(R^{2}=0.85\right)(n=36)\end{array}$ & 104.41 & 3.00 & 313.00 \\
\hline Banana & $\begin{array}{l}Y_{4}=-20788.49+529.65 X_{4}-1.783 X_{4}^{2} \\
\left(R^{2}=0.93\right)(n=22)\end{array}$ & 101.00 & 7.22 & 729.00 \\
\hline Cotton & $\begin{array}{l}Y_{5}=-1277.66+69.5 X_{5}-0.526 X_{5}^{2} \\
\left(R^{2}=0.73\right)(n=27)\end{array}$ & 23.90 & 27.60 & 660.00 \\
\hline
\end{tabular}
for different crops in the season.

\section{Estimation of VMP as a function of water used}

Table 1. Quadratic functions for different crops and the VMP 
The demand for irrigation water is a derived demand where price and quantity of water used are related. Under the neoclassical micro economic modeling framework, the value of marginal product of the input can be used as the demand for that input curve in the short run (Ashenfelter and Layard, 1986; Baumol and Blinder, 2005). In the present paper, using the results of production function for various crops, the value of marginal products (VMP) was derived for each crop as shown in Table 1. The VMP and water requirements of the different crops are presented in Table 2. This value of marginal product of each crop and its total water requirement were plotted in the histogram (Fig. 2). By arranging the crops in the descending order of the value of marginal value of the irrigation water, an approximate of the value of marginal productivity curve for irrigation water was obtained. Then using this data, an exponential form of the demand curve for water was derived (Fig. 3). The values of a, $k$ of this exponential function of the Fig. 3 were taken for the final calculation of stabilization value.

Table 2. Value of marginal product (VMP) and total water used for different crops

\begin{tabular}{lcc}
\hline Crop & $\begin{array}{c}\text { VMP } \\
\text { (Rs) }\end{array}$ & $\begin{array}{c}\text { Total water used } \\
\text { (ha cm) }\end{array}$ \\
\hline Banana & 729 & 1,140 \\
Cotton & 660 & 2,530 \\
Sugarcane & 521 & 11,520 \\
Coconut & 313 & 65,458 \\
Paddy & 263 & $1,67,546$ \\
\hline
\end{tabular}

Note: Total water used was arrived in a cumulative manner taking the midpoint values in the histogram

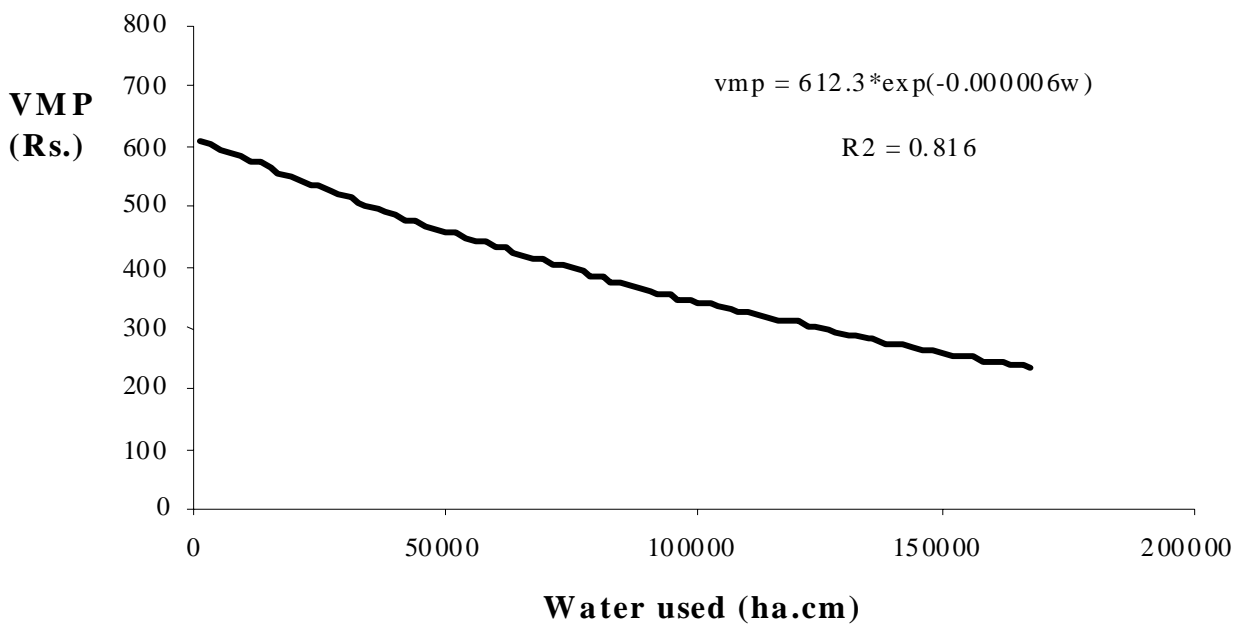

Fig. 3. Estimated VMP as a function of water used

For each tank the values of ground water and surface water were calculated by the above method. Let $S_{t} t=1,23,12$ denote the surface water realization for 12 tanks. Let $g_{t}$ be the ground water demand in each tank associated with $S_{t}$ and $\pi\left(S_{t}+g_{t}\right)$ be the corresponding 
profit. The value of the ground water when surface water supply was $\mathrm{S}_{t}$ equals $\pi\left(\mathrm{S}_{\mathrm{t}}+\mathrm{g}_{\mathrm{t}}\right)$ $\pi \mathrm{S}_{\mathrm{t}}$. The average was calculated by the following formula (Tsur, 1997).

$$
\text { (1/12) } \sum_{i=1}^{i=12}\left[\pi\left(\mathrm{S}_{\mathrm{t}}+\mathrm{g}_{\mathrm{t}}\right)-\pi\left(\mathrm{S}_{\mathrm{t}}\right)\right]
$$

The profit with groundwater minus the profit without groundwater gives the value of groundwater had surface water been stable at the mean level. The difference between the ground water value (Table 3) and the ground water value at mean (Table 3) gives the stabilization value. The results are presented in the Table 3.

The average value of ground water equals to specify Rs. 1966150. The profit assuming that the tank water supply was stable at mean level (3,329 ha.cm) equals to Rs. 1675027 , the difference between these two rows is specify Rs. 2,91,123 which is the stabilization value of the groundwater.

Table 3. Profit and stabilization value of ground water

\begin{tabular}{lccccc}
\hline Tank & $\begin{array}{c}\text { Tank } \\
\text { water (S) } \\
\text { (ha cm) }\end{array}$ & $\begin{array}{c}\text { Ground } \\
\text { water (G) } \\
\text { (ha cm) }\end{array}$ & $\begin{array}{c}\text { Profit (S) } \\
\text { (Rs) }\end{array}$ & $\begin{array}{c}\text { Profit } \\
\text { (S+G) } \\
\text { (Rs) }\end{array}$ & $\begin{array}{c}\text { Profit } \\
(\mathbf{( S + G ) - S )} \\
\text { (Rs) }\end{array}$ \\
\hline 1 & 40070 & 2942 & 21644850 & 22934727 & 1289878 \\
2 & 16952 & 6578 & 9800126 & 13112293 & 3312167 \\
3 & 17459 & 7334 & 10078045 & 13749873 & 3671828 \\
4 & 25027 & 3816 & 14126869 & 15966752 & 1839883 \\
5 & 25569 & 3986 & 14409788 & 16323843 & 1914056 \\
6 & 29046 & 2343 & 16202858 & 17308715 & 1105857 \\
7 & 30065 & 3156 & 16721247 & 18197108 & 1475861 \\
8 & 7579 & 469 & 4505767 & 4761591 & 255824 \\
9 & 8036 & 5643 & 4770918 & 7789475 & 3018557 \\
10 & 10022 & 6272 & 5914725 & 9220461 & 3305736 \\
11 & 6701 & 448 & 3994235 & 4240004 & 245769 \\
12 & 7616 & 4003 & 4527378 & 6685757 & 2158380 \\
Average & 18679 & 3916 & 10558067 & 12524217 & 1966150 \\
Profit at average S & 18679 & $3329 *$ & 10743325 & 12418352 & 1675027 \\
Stabilisation value of ground water (Rs) & & & 291123 \\
Proportion of stabilisation value to total value of ground water (\%) & 15 \\
\hline \multicolumn{5}{l}{}
\end{tabular}

* Average ground water used given, is the average of groundwater used for three years (2004-05, 2005-06 and 2006-07)

This was the value of groundwater due to its role in stabilizing the supply of irrigation water disregarding its role in increasing average supply of irrigation water. The stabilization value of groundwater accounted for about $15 \%$ of the total value of groundwater assuming that tank water supplies were stable at the mean would bias assessments of groundwater benefits downward by $15 \%$. The results thus confirm that the positive and higher value of groundwater in the tank system thus justifying the need for investment in wells in the tank command area. 


\section{CONCLUSIONS}

Most of the tanks in Tamil Nadu are not in a good state and have not been repaired for a long time. Tank water is sufficient for only about 2 months and rice crop normally suffers water shortage and significant yield reduction (700 - 800 kg/ha). Hence, given the importance of stabilization value of groundwater in the tank systems as indicated in the study, it is warranted that supplemental irrigation through groundwater should be provided to stabilize the crop yield.

Management of Tanks: Even though well investment is attractive and there is a potential for additional wells, most of the farmers could not invest in wells as more than $85 \%$ of the farmers are marginal and small farmers.

\section{REFERENCES}

Ashenfelter, O.C. and Layard, R. (1986). Handbook of Labour Economics. Amsterdam: North-Holland.

Baumol, W.J. and Blinder, A.S. (2005). Microeconomics, principles and policy, Ninth edition, South Western, New Delhi, India. pp. 321-3.

Government of Tamil Nadu (1996). Water management in Tank Command- Results from On-farm Development Works, Agricultural Engineering Department, Madurai, Various records.

Palanisami, K. (2000). Tank Irrigation. Revival for Prosperity, Asian publication services, NewDelhi, India.

Palanisami, K. and Easter, K.W. (2000). Tank Irrigation in the $21^{\text {st }}$ Century - What Next?, Discovery Publishing House, New Delhi, India.

Ranganathan, C.R., and Palanisami, K. (2004). Modeling Economics of Conjunctive Surface and Groundwater Irrigation Systems, Irrigation and Drainage Systems, 8(2), 127-143.

Tsur, Y. (1997). The Economics of Conjunctive Ground and Surface Water. In. Parker, D. and Tsur, Y.(Ed.) (1997), Decentralization and co-ordination of Water Resource Management, Kluwer Academic Publishers, London, UK. 